\title{
Digitala körsimulatorer i yrkesutbildning: Utmaningar och möjligheter
}

(Digital driving simulators in vocational education: Challenges and opportunities)

\section{Susanne Gustavsson, Giulia Messina Dahlberg \& Ingrid Berglund}

Göteborgs universitet, Sverige (susanne.gustavsson@ped.gu.se)

\begin{abstract}
This article discusses the didactical challenges and opportunities of driving simulatorsupported teaching and learning, mediated through digital technology in vocational educational and training through the example of driving simulators. We highlight relevant research on simulator-supported teaching and the need for practice-based, empirically driven research. The study is part of a larger project that focuses on the implementation of simulator environments in three secondary schools in the natural resource programme. The data consists of three action research projects in two of these schools where vocational teachers, together with researchers, plan and implement teaching with driving simulators as a new technology in their practice. The article is an example of how action research can contribute to critical evaluation and development of teachers' professional work during the implementation of new technology. Results from these projects are analysed using the TPACK framework. The vocational teacher has a central position to 'master' the digital tool. Issues about fidelity, transfer and progression are discussed in terms of concepts that are challenged when new technology is introduced. Here, the vocational teacher's professional and content knowledge as well as the teacher's didactic and technical competence are central for the development of new strategies when the conditions for teaching change fundamentally.
\end{abstract}

Keywords: vocational education and training, driving simulator, simulator-supported teaching, learning, action research 


\section{Inledning}

Körsimulatorer är ett exempel på digitala verktyg som används i yrkesutbildning. Med simulator i yrkesutbildning avses här en resurs som fiktivt gestaltar användning av ett redskap, en yrkesrelaterad uppgift eller en situation på ett säkert och kontrollerbart sätt (Hirsch, Bellavance, Tahari \& Faubert, 2015; de Winter, van Leuween \& Happee, 2012). Simulatorn som digitalt läromedel i undervisningen förväntas skapa förutsättningar för elevens lärprocess och utveckling av yrkeskunnande via olika typer av övningar samt återkoppling av resultat. Undervisningen kan individualiseras till exempel genom upprepning eller anpassning av övningar. Simulatorer kan dessutom skapa individuella lösningar för elever i behov av särskilt stöd (Cox, Brown, Ross, Moncrief, Schmitt, Gaffney \& Reeve, 2017). Det finns således flera användningsområden och argument för simulatorer i yrkesutbildning, men det saknas i hög grad kunskap om simulatorns betydelse för elevens lärande. Samtidigt behövs kunskap om lärares didaktiska strategier och val när det gäller organisering och genomförande av simulatorstödd undervisning. Implementering av olika typer av digital teknik i skolan har ofta inneburit en tämligen okritisk inställning till hur dessa kan användas och integreras i undervisning (t.ex. Palak \& Walls, 2014). Trots att mer än 20 år har passerat sedan första IT-satsningen i svensk skola, ses digitala verktyg än idag som "lösningen" till många problem, från effektivisering av undervisning, till ökad anpassning samt som verktyg för dokumentation. Digital teknik och "skolans digitalisering" fortsätter att retoriskt presenteras i dikotomiska och onyanserade termer: antingen är läraren och eleven en vän av teknik eller så är de inte det. Många satsningar som görs i skolan och som ger positiva effekter på elevernas förutsättningar är fortfarande ett resultat av enskilda eldsjälars arbete. Ibland kan satsningar vara ett resultat av skolledningens vision och samarbete med privata och vinstdrivande edtechföretag, som numer utgör och leder den övervägande större delen av de pedagogiska satsningar som görs i skolan när det gäller implementering av digital teknik (i denna studie körsimulatorer) i undervisning.

Föreliggande artikel belyser dessa spänningar som vi menar behöver undersökas från ett perspektiv som problematiserar antagandet att digital teknik möjliggör mer anpassade och flexibla undervisningsformer per se, utan att närmare granska relationen mellan ämnesinnehållet, användare (både lärare och eleven) och digital teknik, samt hur den senare omformar en social praktik. Etnografisk forskning som bygger på longitudinella observationer (där dokumentation med rörliga bilder och annan visuell teknik är en förutsättning) och där analysen fokuserar på det som görs i en praktik, snarare än talet om en praktik, behövs för att kunna belysa hur digital teknik används, samt vilka hinder och möjligheter den erbjuder i en specifik praktik. Detta fokus eller intresse bygger på en förståelse av lärande och utveckling som situerade i en social praktik där användare och sociokulturella artefakter samspelar. 


\section{Syfte och frågeställningar}

Studiens syfte är att undersöka samt kritiskt granska utmaningar och möjligheter vid simulatorstödd undervisning i gymnasial yrkesutbildning med fokus på undervisning och på elevers lärprocess. Mer specifikt, vad kännetecknar undervisning med körsimulatorer när kunskapsinnehåll, undervisningsformer samt digital teknik behöver samverka och vilken betydelse får det för undervisningen? Vilka konsekvenser får det för lärarens val av stödstrukturer i undervisningen? Vilken roll spelar simulatorer i undervisningen för att stödja elevens utveckling av yrkeskunnande och övergången till användning av autentiska maskiner?

\section{Bakgrund}

Forskning om simulatorstödd undervisning har, både nationellt och internationellt, fokuserat på simulering inom luftfart, sjöfart och sjukvård, främst inom högre utbildning (Dahlstrom, Dekker, Van Winsen \& Nyce, 2009; Korteling, Helsdingen \& Sluimer, 2017; Petzold, Weiss, Krems \& Bannert, 2013). Körsimulering har främst studerats som ett instrument för att bedöma och undvika en del potentiellt farliga beteenden i trafiken, då mest med koppling till unga förare (Hirsch m.fl., 2015), samt för att bedöma simuleringens autenticitet och validitet som verktyg för träning av körning i olika situationer (Petzold m.fl., 2013) och med förare med en diagnos inom autismspektrum (Reimer, Fried, Mehler, Joshi, Bolfek, Godfrey, Zaho, Goldin \& Biederman, 2013; Cox m.fl., 2017). Forskning inom körsimulering fokuserar även på utveckling och utvärdering av tekniken och hur användarens körning $i$ en simulerad miljö förhåller sig till en "autentisk situation" via prestationer hos erfarna förare. Simulering i en fiktiv, digital miljö blir således en ett verktyg för att träna i säkra förhållanden med syfte att dels utveckla de färdigheter som krävs för körning, dels för att jämföra beteende vid körning $i$ en simulator med körning i en autentisk situation hos den erfarna föraren. Exempelvis i Petzold med flera (2013), studeras förarens beteende (blickens rörelse) i en simulerad körning där nybörjare och erfarna förare jämförs i olika scenarier. Syftet med studierna handlar således mer om utveckling och optimering av simuleringsteknik som sådan, än om exempelvis relationen i en didaktisk praktik där den digitala miljön, användare och instruktör samspelar.

Relevanta spår i forskning om simulering i pedagogiskt syfte, dock inte med specifikt fokus på körning av bil eller andra maskiner, är studier som rör simulering som spel, samt i förhållande till innehållet $i$ undervisning $i$ termer av stödstrukturer (scaffolding) och överföring av kunskaper mellan olika sammanhang (transfer). Enligt Fu-Hsing, Charles, Kuo-Hsun, Cheng-Ling och I-Ying (2013), innebär digital simulering och dess utformning som spel att eleven tenderar att fokusera på spelet (i termer av att befinna sig i spelet och klara av dess utmaningar), snarare än att fokusera på det avsedda kunskapsinnehållet. Med andra 
ord, möjligheten att skapa "immersive experience" hos eleven i den digitala simulerings-/spelmiljön innebär inte per automatik att eleven kommer i kontakt med och utvecklar relevant kunskap. Att stötta elevernas lärande (genom scaffolding) utan att avbryta spelets "flow", blir således en central fråga i arbetet med digital simulering (Fu-Hsing m.fl., 2013).

Begreppet transfer och mer specifikt transfer-of-training (Korteling m.fl., 2017) används för att belysa relationen mellan det yrkeskunnande som är i fokus i utbildning och sätten på vilka detta kunnande används i en yrkeskontext (Aarkrog, 2011). Generellt sett kan flera liknelser mellan simulerade scenarier i en utbildningssituation (inklusive deras fysiska, funktionella och psykiska element) och den "riktiga världen" innebära att transfer av kunskaper mellan dessa två situationer kan ske. Korteling med flera (2017) hävdar dock att förhållandet mellan utbildning och yrkesliv är mer komplext. Att förutse vilket lärande som sker i en utbildningssituation och dess inverkan på det som äger rum i olika situationer i en mer eller mindre nära framtid är mycket svårt. De didaktiska aspekterna gällande val av kunskapsinnehåll, undervisningsformer och genomförande som är inbäddade i simuleringsmiljön, samt lärares kunskaper blir avgörande. Det räcker således inte med hög autentisk faktor eller fidelitet i en simuleringsmiljö om inte relevanta didaktiska beslut tas i samband med undervisning i förhållande till exempelvis svårighetsgrad, vad som görs (o)synligt i miljön och hur det som simuleras behandlas i undervisningen på ett mer abstrakt och generellt plan (Korteling, m.fl., 2017).

I en yrkesutbildning, förutsätts att den skolförlagda delen av utbildningen och lärandet på arbetsplatsen är starkt sammankopplade. I vissa fall finns förväntningar att den kunskap eleven utvecklar under utbildningen ska motsvara arbetsuppgifter som ingår i yrket. Idén om att eleverna lär sig under utbildning för att kunna genomföra mer eller mindre specifika arbetsuppgifter i yrket har behandlats i forskningen i termer av "boundary-work" eller "boundary-crossing" (t.ex. Akkerman \& Bakker, 2011; Gieryn, 1983; Llewellyn, 1998; Tuomi-Gröhn \& Engeström, 2003). Detta kan även gälla pendlingen mellan lärmiljöer under yrkesutbildningen och uppfattningen om vad eleven "ska ta med sig" för kunskaper mellan miljöerna, men också vad respektive miljö kan erbjuda eleven och hur kunskap kan integreras. Den så kallade teori- och praktikrelationen utmanas därmed. Begreppet transfer kan användas för att förstå hur rörelser mellan olika praktiker är länkade men också separerade från varandra, med tydliga gränser i tid och rum (Aarkrog, 2011). Gränsöverskridande utbildning mellan kontexter (och fysiska rörelse där emellan) är centrala aspekter menar Berner (2010), med stöd i Gieryn (1983). Gränsarbete (boundary-work) kan dock innebära att gränserna mellan skola och arbete förstärks, snarare än suddas ut. I en digital miljö som ter sig mycket nära den autentiska miljön och yrkespraktiken, kan gränserna mellan utbildning och yrkesutövning överbryggas, men också förstärkas. 
Sammanfattningsvis, finns behov av studier om simulatorstödd undervisning i yrkesutbildning. Studier om simulatorer i annan kontext eller studier om spel saknar relationen till lärprocesser och kunskapsutveckling. Relationen mellan övning av yrkeskunskap via simulatorer och på arbetsplats avseende vad eleven lär sig i de olika miljöerna, och hur undervisningen bäst kan designas för att dra nytta av de möjligheter som en simulator erbjuder är hittills okänd kunskap. Undervisningsnära studier är ett sätt att närma sig dessa frågor.

\section{TPACK-modellen som analysredskap}

I analysen av hur undervisningen tar form när körsimulatorer tas i bruk används teorin om Technological Pedagogical Content Knowledge (TPACK) (Herring, Koehler \& Mishra 2008; Koehler \& Mishra, 2009; Mishra \& Koehler, 2006). TPACK framställs som en modell för hur olika kunskapsområden tar sig uttryck, formas och samverkar i undervisning när tekniska redskap används. Den är en utveckling av Lee Shulmans $(1986,1987)$ teori om Pedagogical Content Knowledge (PCK). PCK uppstår när två kunskapsområden, Pedagogical Knowledge (PK) och Content Knowledge (CK) samverkar och förenas i undervisning, vilket resulterar i att ett tredje specifikt kunskapsområde uppstår, PCK. Med användningen av allt fler tekniska och digitala redskap i undervisning utgör teknisk kunskap ytterligare ett kunskapsområde i förhållande till pedagogisk kunskap och innehållskunskap (Angeli \& Valanides, 2009; Graham, Borup \& Smith, 2012).

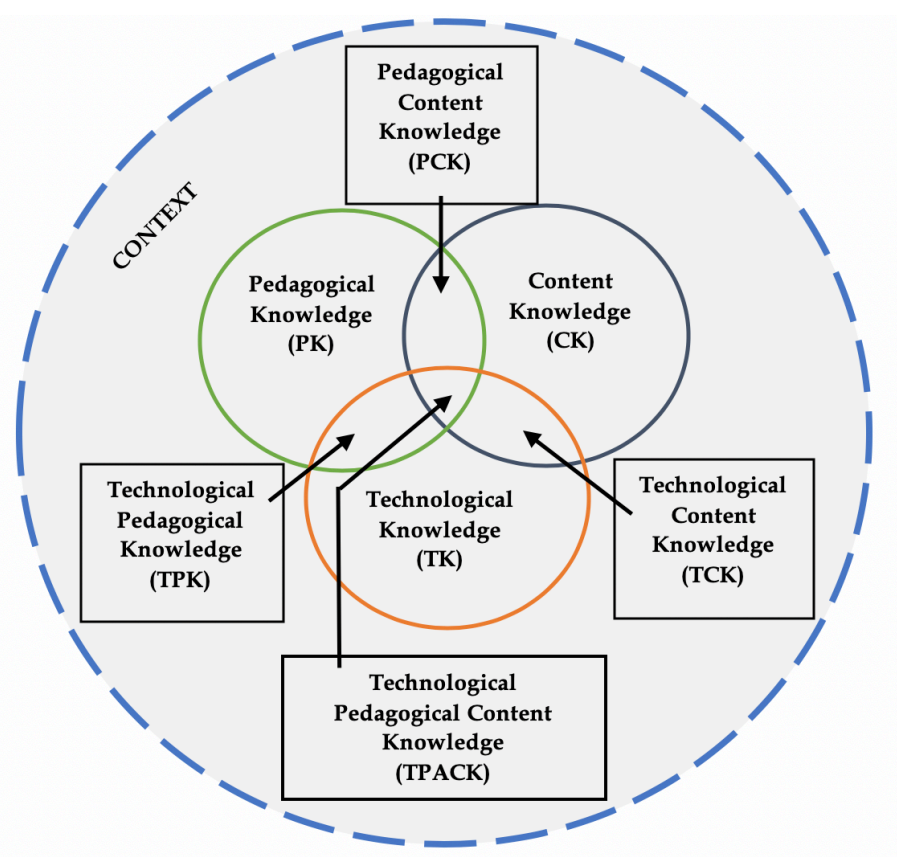

Figur 1. TPACK-modellen och dess kunskapsområden (modifierad från Koehler $\mathcal{E}$ Mishra, 2009). 
Den visualiserade modellen av TPACK visar att när teknisk utrustning används i undervisning uppstår flera nya kunskapsområden i förhållande till PCK: teknisk kunskap (TK), det tekniska ämnesinnehållet (TCK) och teknikdidaktisk kunskap (TPK). Dessa kunskapsområden samverkar och nya integrerade kunskapsområden uppstår (som synliggörs i de överlappande fälten i modellen). Att använda TPACK-modellen som analytiskt redskap innebär att undervisning som involverar användning av teknik undersöks utifrån följande aspekter: de tekniska redskap som används, ämnesinnehåll och i vilken kontext undervisningen sker samt den didaktiska och tekniska kunskap undervisande lärare har. Det innebär att lärare som vill integrera tekniken i sin undervisning måste vara kompetenta inom modellens tre områden (Voogt, Fisser, Pareja Roblin, Tondeur \& van Braak, 2013). Herring med flera (2008) uttrycker att undervisning med stöd av teknisk utrustning är situerad i en specifik kontext och tar därför form på varierande sätt. Därför är det av vikt att beskriva sammanhanget för undervisningen vid analyser utifrån TPACK-modellen. Doering, Veletsianos, Scharber och Miller (2009) lyfter fram TPACK-modellens dynamiska karaktär och det ömsesidiga förhållandet mellan kunskap i ett skolämne och det som sker i undervisningen. Cox och Graham (2009) synliggör utförligt i konceptuella analyser av de integrerade fälten i TPACK-modellen innehållet i de nya, specifika och integrerade kunskapsområden som skapas utifrån användning av teknik i undervisningen (se även Figur 1). I föreliggande studie används TPACK för att identifiera motsvarande fält och dess utmaningar och möjligheter vid simulatorstödd undervisning. TPACK bidrar således till att synliggöra kunskapsinnehåll, pedagogik och teknik samt hur dessa kunskapsområden samspelar och får betydelse i undervisningen och för lärarens val av stödstrukturer.

\section{Metod}

Studien genomförs vid två gymnasieskolor som använder digitala körsimulatorer i naturbruksutbildning, med inriktning mot skog respektive lantbruk. Från att undervisningen tidigare enbart har kunnat ske i autentisk miljö i skola och på arbetsplats, finns nu simulatormiljöer. Simulatormiljöerna är resultat av ett externfinansierat fyraårigt utvecklingsprojekt som har skapat möjligheter att inreda undervisningslokaler särskilt avsedda för simulatorstödd undervisning. Denna förändring får betydelse främst för yrkeslärarens arbete, där miljön skapar nya villkor för undervisningen. Yrkeslärare med ansvar för utbildning inom körteknik och angränsande arbetsuppgifter har involverats i den lokala processen att organisera simulatormiljöer och utformningen av simulatorstödd undervisning.

Yrkesutbildningens styrdokument samt yrkesbranschens behov av kompetens har varit vägledande för val av simulatorer och utveckling av miljön. Ett särskilt mål har varit att skapa så goda förutsättningar som möjligt för att alla elever ska utveckla relevant yrkeskunskap. Andra incitament var miljöaspekter, 
ekonomi, säkerhet och tillgänglighet. Utvecklingen av simulatormiljöer i dessa skolor har således haft flera övergripande motiv som rör undervisningspraktiken och utbildningen. Yrkeslärares medverkan i skapande av simuleringsmiljöer har genererat samtal om undervisning, om konsekvenser för elevers lärprocesser och utveckling av yrkeskunskap. Efterhand har dessa samtal och frågor skapat intresse för undervisningsnära studier som mer systematiskt undersöker villkor, förutsättningar och effekter kring simulatorstödd undervisning.

I samband med arbetet med utveckling av simulatormiljöer i respektive skola, startade projektet Yrkesutbildning och Simulering (YRKSIM) där yrkeslärare tillsammans med forskare identifierade frågeställningar som utgångspunkt för undervisningsnära projekt. Studiens data genererades vid tre aktionsforskningsprojekt i två skolor, som här benämns skola A och B. YRKSIM inleddes med ett heldagsmöte där yrkeslärare, skolornas IKT-pedagog samt forskare genomförde kartläggning av yrkeslärarnas undervisningskontexter, formulerade frågeställningar och aktioner. Avslutningsvis bestämdes en plan för tre aktionsforskningsprojekt (Figur 2).

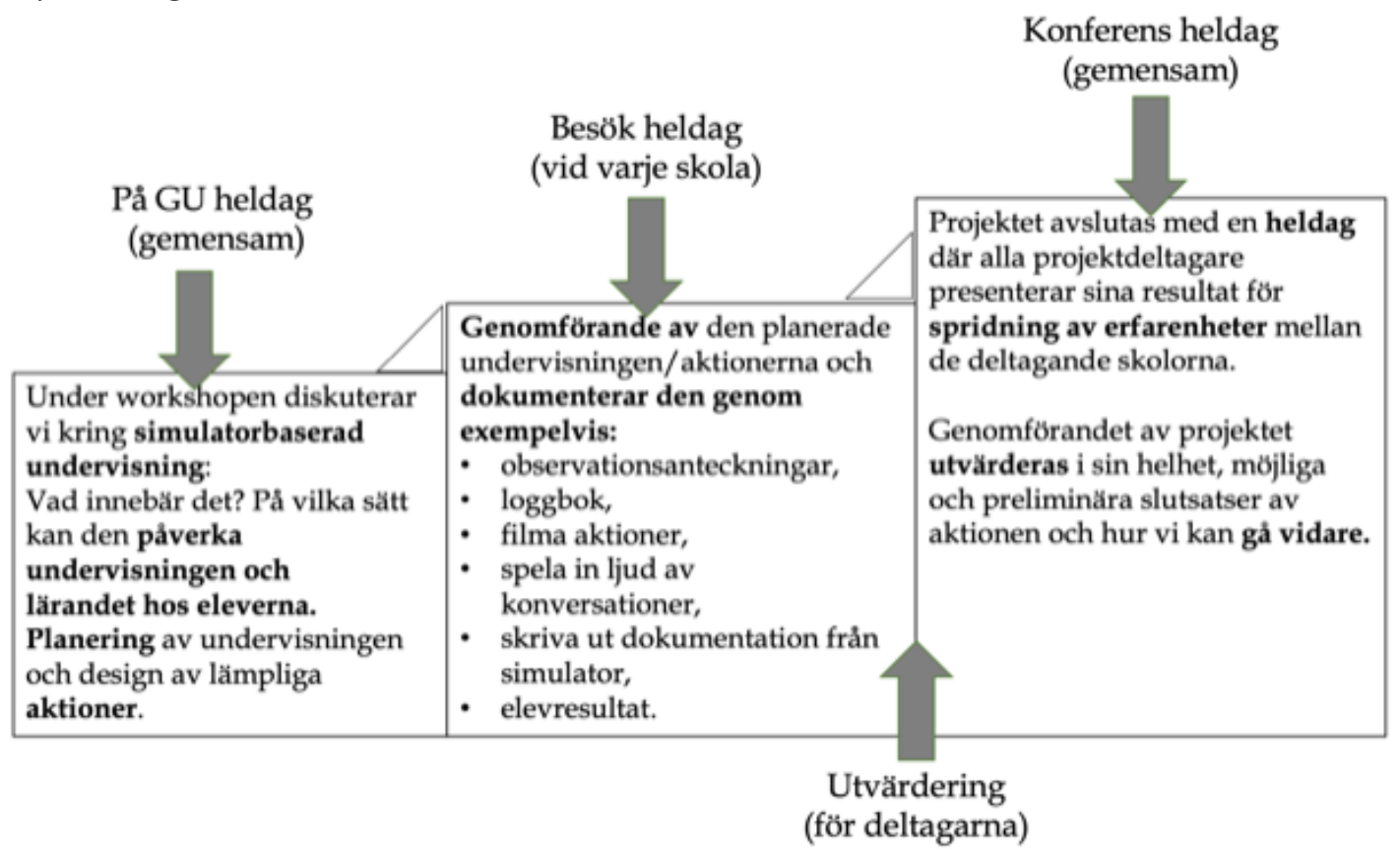

Figur 2. YRKSIM - Projektdesign.

Aktionsforskningsprojekten följde den spiralformade processen: planera, agera, observera och reflektera (Hardy, Rönnerman, Edwards-Groves, Fumasoli, Stensaker \& Vukasovic, 2018), vilket gav möjlighet att både identifiera, pröva och utvärdera frågeställningar direkt knutna till simulatorstödd undervisning. De tre aktionsforskningsprojekten hade delvis olika syften och mål utifrån de behov som identifierades och prioriterades. Dock hade samtliga projekt tydligt fokus på 
de didaktiska utmaningar och möjligheter som var en följd av planering och genomförande av simulatorstödd undervisning. En forskare knöts till varje skola. Sammanlagt fyra yrkeslärare var involverade. Aktioner, uppföljningar samt analyser genomfördes av yrkeslärare och forskare i samarbete. En forskare medverkade i projektet på Skola A tillsammans med två yrkeslärare (Aktionsforskningsprojekt 1), en forskare medverkade i de två projekten på Skola B (Aktionsforskningsprojekt 2 och 3) tillsammans med en yrkeslärare i respektive projektet. I resultatavsnittet ges en mer utförlig beskrivning av skolorna och aktionsforskningsprojekten inom YRKSIM (se Figur 2).

Studiens data hämtades från yrkeslärarnas uppföljning av respektive aktionsforskningsprojekt samt forskares loggböcker och intervjuer. Mer precist skapades följande data:

Tabell 1. Metoder för uppföljning av aktioner.

\begin{tabular}{|c|c|c|}
\hline $\begin{array}{l}\text { Skola A } \\
\text { Aktionsforskning } 1\end{array}$ & $\begin{array}{l}\text { Skola B } \\
\text { Aktionsforskning } 2\end{array}$ & $\begin{array}{l}\text { Skola B } \\
\text { Aktionsforskning } 3\end{array}$ \\
\hline $\begin{array}{l}\text { Elevers självvärderingar } \\
\text { med stöd av ett fram- } \\
\text { ställt underlag }\end{array}$ & $\begin{array}{l}\text { Systematiska elev- } \\
\text { observationer med hjälp } \\
\text { av olika matriser }\end{array}$ & $\begin{array}{l}\text { Systematiska elev- } \\
\text { observationer med hjälp } \\
\text { av olika matriser }\end{array}$ \\
\hline $\begin{array}{l}\text { Lärares observationer } \\
\text { av undervisning med } \\
\text { stöd av observations- } \\
\text { mall }\end{array}$ & $\begin{array}{l}\text { Lärarens observations- } \\
\text { anteckningar } \\
\text { Stillbilder och rörliga } \\
\text { bilder }\end{array}$ & $\begin{array}{l}\text { Lärarens observations- } \\
\text { anteckningar } \\
\text { Stillbilder och rörliga } \\
\text { bilder }\end{array}$ \\
\hline $\begin{array}{l}\text { Inspelade gruppinter- } \\
\text { vjuer med elever } \\
\text { Kontinuerliga doku- } \\
\text { menterade samtal mel- } \\
\text { lan lärare och forskare }\end{array}$ & $\begin{array}{l}\text { Kontinuerliga doku- } \\
\text { menterade samtal mel- } \\
\text { lan lärare och forskare }\end{array}$ & $\begin{array}{l}\text { Kontinuerliga doku- } \\
\text { menterade samtal mel- } \\
\text { lan lärare och forskare }\end{array}$ \\
\hline
\end{tabular}

Data analyserades först var för sig och därefter gemensamt med utgångspunkt i studiens syfte att undersöka samt kritisk granska utmaningar och möjligheter vid simulatorstödd undervisning. I analysen användes TPACK för att dels identifiera och beskriva de tre kunskapsområdena PK, CK och TK (Figur 1), dels för en övergripande analys av vilken form TPACK antar i de tre aktionsforskningsprojekten. Utmaningar och möjligheter identifierades via de mönster som framträdde i analysen. 
Medverkande lärare och elever var informerade om forskningsetiska principer om frivillighet, samtycke, konfidentialitet och nyttjande i samband med aktionsforskningsprojekten. Lärarna har även gett sitt godkännande till användningen av data i föreliggande artikel.

\section{Resultat}

De tre aktionsforskningsprojekten bildar utgångspunkt för studiens resultat. Inledningsvis presenteras aktioner, uppföljning och resultat för respektive projekt. Därefter görs en sammanfattande och fördjupad analys med stöd av TPACKmodellen.

\section{Skola A: Körning av skogsmaskiner}

Den aktuella undervisningen i Skola A gäller körning av skördare och skotare. En skördare är en terränggående maskin som kapar, kvistar och avpassar ett träd till stockar och en skotare är ett terrängfordon som används för transport av virke från avverkningsplatsen till en uppläggningsplats (Figur 3).

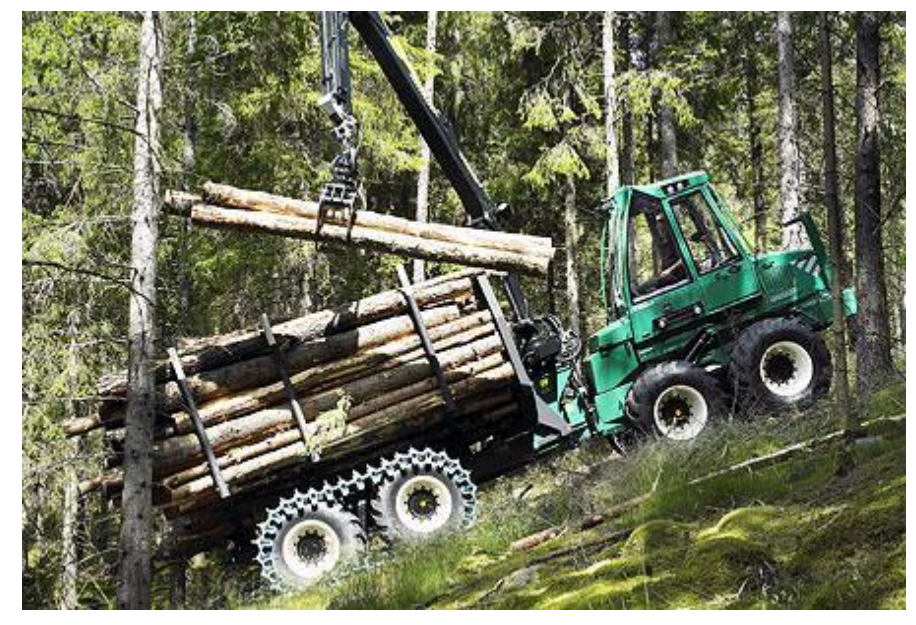

Figur 3. Skotare.

Körsimulatorerna finns i ett centralt beläget simulatorcenter i Skola A (Figur 4). När YRKSIM-projektet startar finns märkesspecifika körsimulatorer, vilket innebär att de exempelvis har samma typ av styrdon (joysticks) som en autentisk maskin av motsvarande modell. Under projektets gång tillkommer nya, och mer avancerade körsimulatorer i form av kombinationssimulatorer som kan anpassas till olika maskiner genom byte av styrdon, samt datorprogram som simulerar olika slags maskiner och fordon. 




Figur 4. Simulatorcenter Skola A.

Initialt är en lärare med lång erfarenhet av undervisning i körning av skogsmaskiner, både autentiska och i körsimulator, engagerad i projektet. Senare involveras en yrkeslärare utan tidigare erfarenhet av simulatorstödd undervisning.

Kranhantering vid körning av skotare i simulator (Aktionsforskningsprojekt 1)

Efter kartläggningen av vad som är angeläget att undersöka och utveckla i den aktuella undervisningen riktas aktionen mot lärande av kranteknik vid körning av skotare, vilket är en central kunskap när timmer ska lastas i terräng och en viktig aspekt av ekonomisk körning. Den övergripande frågeställningen är hur simulatorkörning kan utveckla elevers förmåga till ekonomisk körning av skogsmaskiner, samt bidra till en högre ingångsnivå inför körning av autentisk skogsmaskin. Det yrkesämne som ingår i studien är skogsmaskiner och kursen terrängtransporter. Eleverna som representerar flera årskurser engageras som medforskare i projektet genom att ett underlag skapas för självskattning i förhållande till centrala kunskaper i kranhantering för körning av skotare. Inledningsvis gör yrkeslärarna en analys av vad som är centralt kunnande i körningen som resulterar i sex aspekter:

1. Kranrörelser (fysisk/motorisk träning mot automatisering)

2. Utskjutets användning (för effektiva arbetsprocesser)

3. Ekonomisk kranhantering (planering av kortaste väg)

4. Grippunkt (den optimala grippunkten)

5. Knippets lutning (positiv lutning mot grinden)

6. Flyt i kranhanteringen (bör-värde, helhetsbedömning) 
Efter varje övningstillfälle skattar eleverna sin kunskap om respektive aspekt på en skala från 1 till 5 . Uppföljningen i form av elevers självskattning blir parallellt ett redskap för elevers reflektion över sin egen kunskapsutveckling. De olika aspekterna ger även en möjlighet att betona det som framstår som viktigt att lära sig gällande körning av skotare. Yrkeslärarna observerar och dokumenterar elevers kunskapsutveckling vid simulatorkörningen, samt har löpande diskussioner om hur undervisningen kan utvecklas. Elevernas självskattningar sammanställs till grafer och analyseras av lärare och elever. Därefter genomförs elevintervjuer för att ta vara på elevernas erfarenheter av simulatorkörningen.

Utifrån sammanställningen av självvärderingar genomförs två gruppintervjuer med vardera fem elever från årskurs 1 och 2 . Grupperna sätts samman av en yrkeslärare. Vid intervjuerna får eleverna se graferna över sina självskattningar som utgångspunkt för frågor om hur det är att lära sig köra skotare i simulator, och vilken kunskap de uppfattar att de har utvecklat genom simulatorkörningen. Eleverna uppmanas att beskriva vad de har lärt sig och vad de uppfattar som lätt respektive svårt, samt värdera för- och nackdelar vid simulatorkörning av skotare. Vid intervjutillfället har flera av eleverna erfarenheter av körning i autentiska maskiner och uppmanas därför att beskriva skillnader och likheter med simulatorkörningen. Intervjuerna genomförs av den yrkeslärare som inte är direkt involverad i undervisningen och forskaren. Intervjuerna spelas in, avlyssnas av båda yrkeslärarna och transkriberas i sin helhet av forskaren. Resultatet av intervjuer med elever beskrivs nedan i fyra kategorier.

Simulatorövningar för mängdträning och automatisering

Eleverna uppfattar att simulatorkörningen i hög grad handlar om den motoriska träningen.

Det är bara att sitta och nöta egentligen. Bara att sitta och känna på kranen så att man får in alla tekniker samtidigt. (Elev 1)

Att få in alla tekniker samtidigt kan beskrivas som att eleverna ska automatisera handrörelserna, vilket innebär att göra flera handrörelser simultant, men också att planera kranens och utskjutets rörelse så effektivt som möjligt.

Att man får in flera grejer samtidigt. Att du flyttar och får ut utskjutet samtidigt och att du öppnar grinden. Det tycker jag är rätt bra och det tänkte man inte på innan. (Elev 4)

Eleverna uttrycker att det krävs mycket träning för att automatisera kranhanteringen.

Det svåraste är att få ett bra flyt. Att det ska gå så fort och effektivt som möjligt. (Elev 3) 
Alla elever är överens om att simulatorer är bra för körträningen och att de i princip har lärt sig kranrörelserna genom simulatorövningar. Eleverna uttrycker samstämmigt att den motoriska träningen i simulatorer innebär att de är bättre förberedda för autentisk körning.

Öva och bli bättre. För att lära sig och känna in hur det fungerar på ett ungefär för att sedan gå ut och göra det på riktigt. (Elev 5)

Simulatorerna har inbyggda program för olika övningar som används i undervisningen.

Jo, John Deer-simulatorerna har ju ett studentprogram, där du kan gå in och då har du väldigt uppritat vad du ska göra och så poängbedöms det. Simultana kranrörelser och bränsleförbrukning och allt möjligt. Det är ju det som man behöver lära sig. (Elev 5)

I intervjuerna diskuteras de olika simulatorernas upplägg i övningarna, där det stegvisa upplägget som innebär att uppgifterna bygger på varandra uppfattas som mindre stimulerande.

Elev 7: Det är just det att man måste utföra en viss del för att komma vidare.

Elev 8: Om man måste börja om då tröttnar man ju. Först lär du dig att starta traktorn typ, sen åka framåt typ.

Elev 10: Om du ska köra maskin så måste du veta alla delar innan du får gå vidare till nästa.

Elev 7: Kolla alla oljor, göra rent filter.

Som framgått finns det en blandning av märkesspecifika simulatorer och kombinationssimulatorer i skolans utrustning. Eleverna menar att det kan vara bra med olika typer av simulatorer så att de kan få testa olika varianter. Det finns en gemensam standard för styrdonen på skotare, medan andra funktioner kan variera.

Elev 3: Det är ungefär samma spakar. Kranens joystick är nästan uteslutande likadan.

Elev 1: Den är likadan i alla maskiner. Det är bara placeringen av andra olika funktioner, så som lampor och vindrutetorkare - det kan vara olika.

\section{Simulatorer och autentisk körning}

Vid jämförelse av körning i simulatorer med körning i autentiska skotare beskriver elever utifrån sina varierande erfarenheter exempel på skillnader mellan vad som är möjligt att lära sig vid simulatorkörning och vilket kunnande som behöver utvecklas genom autentisk körning. Eleverna framhåller tydligt att simulatorer inte kan ersätta autentisk körning, men den motoriska förmågan i körningen går att utveckla i simulatorerna. De skillnader som lyfts fram är fidelitet som inte går att konstruera fullt ut i simulatorernas datorskärmar, men som har utvecklats betydligt med mer avancerad grafik i de nyare simulatorerna. 
Elev 2: Kanske det där med djupseendet. Det är svårt att se det i simulatorerna. Det är lättare i verkligheten.

Elev 3: Framförallt avståndsbedömningen som är den största skillnaden. Sen är det miljön som blir annan. Det lutar och det låter, men själva krankörningen i maskin är ju exakt densamma.

Elev 5: Det du inte känner i simulatorn, det är lutningen. I dom nya simulatorerna är det en platta som gör att stolen rör på sig. Så om du kör upp på en sten då lutar du. Svänger du för fort så känner du.

Elev 6: Det är ju inte samma att sitta i simulatorerna som i en riktig maskin så det blir inte riktigt samma sak. Man ser inte så bra i simulatorerna.

Elev 7: Dom nya är bättre än dom gamla. Det är mer verkligt. Det är större skärmar och att sätta sig i riktiga stolar...

En annan skillnad som eleverna beskriver gäller terrängkörningen och där stolarna på de nyinköpta simulatorerna kan röra sig i förhållande till den visualiserade terrängen. Användning av VR-glasögon ger ett mer verklighetstroget seende, men som kan skapa illamående.

Jag tyckte att dom var jättebra för då kom man åt och då blir det verkligt om man typ välter nånting. (Elev 10)

Sen har vi dom här VR-glasögonen. Då blir det lite mer verkligt. Men det går inte, jag mår jätteilla av dom. (Elev 6)

\section{Simulatorer och riskfri körning}

I en simulator kan man riskfritt träna farliga situationer där skador annars kan uppstå. Eleverna uttrycker att det inte är säkert att de tänker på att motsvarande situation som simuleras faktiskt kan uppstå i den autentiska körningen.

Elev 1: Sen är det skaderisken, om det händer nåt med föraren där ute i skogen.

Kör du i simulatorn då händer det inget, men är det på riktigt då...

Elev 4: $\mathrm{Oj}$, då. Man får väl börja om då. Men man tänker ju på vad som skulle hända om jag välter på riktigt.

Elev 7: Man tar det mer som ett spel, liksom. Man startar bara om.

Elev 3: På Wimek-simulatorn. Kollision med träd, kollision med maskin. Det står att du har skadat maskinen, typ. Då får man börja om. Om man kör på nån eller har skadat maskinen.

Elev 9: Det är billigare att göra misstag på dom än i riktiga maskiner.

Elev 2: Man tänker att nu har jag lärt mig hur man inte ska göra. Då får man träna på hur man ska göra.

Farliga situationer som uppstår i simulatorn tar eleverna kanske mer för ett spel än som en träning för att undvika sådana situationer när de kör i terräng. Det framgår att det inte finns några övningar i simulatorerna för att reflektera över sådana farliga händelser. Det handlar bara om att starta om simulatorn. 
Yrkeslärares utmaningar och möjligheter till utveckling av undervisningen

Yrkeslärarna lyfter fram flera fördelar med simulatorerna: de kan ge möjlighet till mängdträning, är årstidsoberoende och ger träning i en trygg miljö. Eleverna ges möjlighet att automatisera kranhanteringen i simulatorerna vilket dels främjar ekonomisk körning, dels medför en tidsbesparing då eleverna blir bättre förberedda för körning i autentiska skotare. En utmaning som lärarna särskilt lyfter fram är:

\begin{abstract}
Att eleverna inte respekterar simulatorn som ett redskap för lärande utan istället leker med utrustningen. Det kan skapa negativ inlärning som vi sedan får lida av vid autentisk maskinkörning. Konsekvenser vid våldsam körning uteblir i simulatorkörning, vilket det inte gör i verkligheten. (Ur lärarnas anteckningar)
\end{abstract}

Det finns därför behov av uppföljning av risker i körningen och lärarna menar att de behöver utvärdera sådana situationer i undervisningen genom att exempelvis använda blanketter för tillbudsrapporter. Aktionen skapar också konkreta idéer om hur undervisningen kan utvecklas, och där ämnesintegrering är en viktig aspekt.

\begin{abstract}
Konkret så kommer det fungera som så att vid exempelvis en mattelektion kan en simulatorlärare vara behjälplig för eleverna att skapa siffor eller matteproblem, som sedan används i matematikundervisningen. Tanken är alltså inte att plocka bort 30 procent av maskinkörningen ur maskinkurserna för att dedicera till simulatorkörning, utan snarare att integrera in simulatorerna i en blandning av kurser. (Ur lärarnas anteckningar)
\end{abstract}

Utifrån dessa samtal och frågan om hur lärarna kan använda simulatorerna fortsatt i undervisningen skapas ett förslag till ämnesintegrering och hur innehåll i olika kurser skulle kunna genomföras som uppgifter i samband med simulatorkörning. Det handlar om att exempelvis i årskurs 2 genomföra virkesrapportering och karthantering i samband med övningar i simulator. I årskurs 3 skulle traktdirektiv och egenkontroll kunna bli lämpliga uppgifter. Simulatorerna ger också möjlighet till gruppövningar som kan samordnas med att uppgifterna utförs, en möjlighet som lärarna kan använda i undervisningen fortsatt (Figur 5).

Aktionen handlar om hur simulatorkörning kan utveckla elevers förmåga till ekonomisk körning av skogsmaskiner samt bidra till en högre ingångsnivå vid körning av autentiska skogsmaskiner. Resultatet visar att eleverna utvecklar förmåga till effektiv kranhantering som i sin tur ger bättre förutsättningar för ekonomisk körning. Det framkommer även rika möjligheter att utveckla undervisningen med stöd av körsimulatorer i kombination med körning i autentiska maskiner. Lärarna lyfter genom sina observationer och didaktiska samtal fram vikten av att integrera körningen i simulatorerna med flera yrkesämneskurser och övriga ämnen över hela utbildningen. Eleverna har genom självskattningar med uppföljande samtal reflekterat över det egna lärandet av körning i simulatorer och gett ett viktigt bidrag till förståelsen av vilken kunskap som kan utvecklas vid simulatorkörningen. 


\section{Planering av simulatorundervisning}



Årskurs 1

- Kurs

Terrängtransporter

- Introduktion

- Kranrörelser grund

- Effektiv

kranmetodik

Exempel på arbetssätt och progression


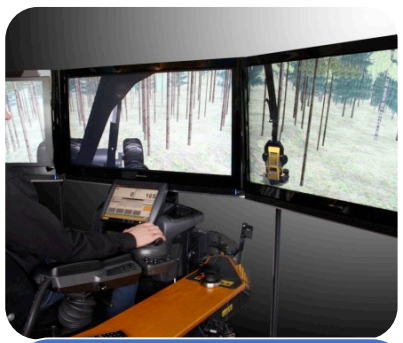

Årskurs 3

- Kurs

Avverkningsmaskiner

- Avverkning

- Traktdirektiv

- Egen kontroll/

uppföljning

Figur 5. Planering av simulatorstödd undervisning. Exempel på kursinnehåll och progression.

Skola B: Simulatorstödd undervisning och förutsättningar för lärande

Lärare och elever vid Skola B har tillgång till en körgård och en simulatormiljö som erbjuder kombinationssimulatorer, märkesspecifika skogs- och lantbruksmaskinssimulatorer samt en trafiksimulator (Figur 6).
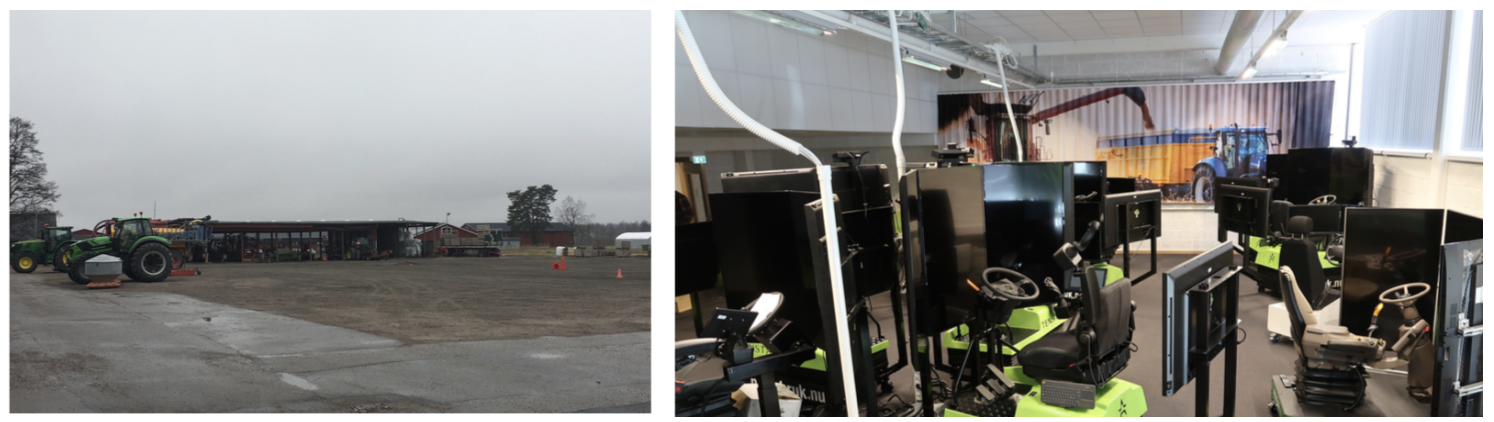

Figur 6. Körgården och simulatorcenter i Skola B.

Två lärare medverkar i projektet och båda har engagerat sig i att utveckla och bedriva simulatorstödd undervisning redan före YRKSIM startade. Två aktioner genomförs inom ramen för YRKSIM, båda med fokus på olika delar av innehåll och kursmål inom ämnet fordonsteknik. Den övergripande frågeställningen som ligger till grund för båda aktionerna syftar till att nå en djupare förståelse för hur simulatorstödd undervisning kan skapa förutsättningar för lärande i förhållande 
till ämnets syfte och dess centrala innehåll. Med detta som utgångspunkt, identifieras några områden för planering och genomförande av olika moment i undervisning: körning av, samt kunskapen om, skördetröskan (Aktionsforskningsprojekt 2) och trafikregler i samband med körning av basmaskin (Aktionsforskningsprojekt 3). En mer detaljerad redovisning av varje projekt presenteras nedan.

Undervisning i skördetrösksimulator (Aktionsforskningsprojekt 2)

Detta aktionsforskningsprojekt har sin utgångspunkt i den övergripande frågeställningen: hur kan undervisningen på befintlig märkesspecifik skördetröska planeras och genomföras för att skapa förutsättningar för lärande, mängdträning och förberedelse för att köra tröskan i skoljordbruket? Mer specifikt, hur påverkar de engelska instruktionerna för simulatorövningarna elevens möjligheter att dels uppfatta övningen, dels ge större ordförråd i, och motivation för det engelska språket? Samtliga simulatorövningar är självinstruerande med text och bild. Valt språk är engelska; nordiska språk är inte tillgängliga då simulatorn är direktimporterad från USA. Sex elever i årskurs 1 följs och observeras under simulatorövningar som består av Practice (övning) och Assessment (bedömning); exempelvis, Maneuvring, Basic harvesting och Intermediate harvesting. Uppföljningen sker via yrkeslärarens observationer utifrån en matris där anteckningar förs in på ett systematiskt sätt, bland annat aktuella moment i relation till kommande steg i övningen, och kompletteras med korta samtal med elever.

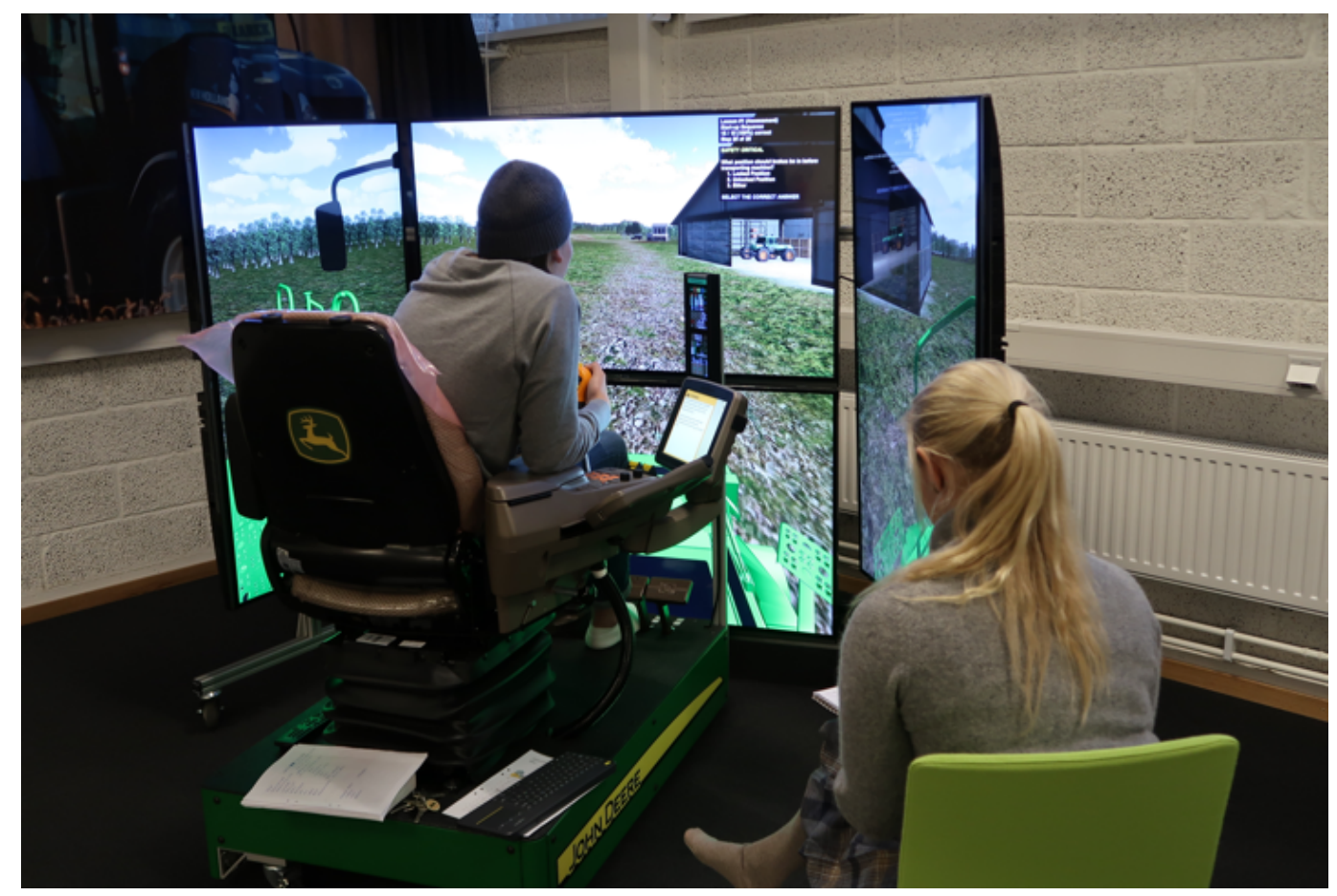

Figur 7. Körning av tröskan i simulator. 
Sex elever i årskurs ett observeras under genomförande av fyra övningar i simulatorn och momenten "Practice" och "Assessment" (se Tabell 2). Eleverna får ta del av instruerande fackuttryck och information om vad som ska göras under övningen samt beskrivande fackuttryck om tröskans instrument och reglage (Figur 7). Eleverna har olika förkunskaper i att köra tröska och i engelska. Fyra elever observeras enskilt och två elever tillsammans.

Tabell 2. Övningar i märkesspecifik trösksimulator (ur lärarens anteckningar).

\begin{tabular}{|l|l|}
\hline Övning 1 & $\begin{array}{l}\text { Operator knowledge/Transport controls } \\
\text { Övningen handlar om att i 55 steg lära sig användning av for- } \\
\text { donets reglage och tolkning av instrument samt göra upp- } \\
\text { startsmoment på tröskan. Practice-momentet är instruerande i } \\
\text { både engelska ord och i bild. På Assessment-momentet ska } \\
\text { man klara testet utan dessa instruktioner. }\end{array}$ \\
\hline Övning 2 & $\begin{array}{l}\text { Maneuvering } \\
\text { Eleven gör här ett uppstartsmoment av tröskan, backar ut den } \\
\text { ur ett garage samt kör en landsvägsrunda i trafik. }\end{array}$ \\
\hline Övning 3 & $\begin{array}{l}\text { Basic harvesting } \\
\text { Efter uppstart av maskinen tröskas ett regelbundet fält med } \\
\text { vald gröda och tröskans tank töms stillastående vid fältkant. }\end{array}$ \\
\hline Övning 4 & $\begin{array}{l}\text { Intermediate harvesting } \\
\text { Eleven gör uppstart av tröskan, tröskar ett fält med böljande } \\
\text { svängar och med avsmalnande och ökande bredder av fältet. } \\
\text { Det kan uppkomma plötsliga hinder i fältet och tanktömning } \\
\text { görs i farten. }\end{array}$ \\
\hline
\end{tabular}

Utifrån lärarens uppföljande dokumentation under elevernas genomförande av övningarna, urskiljs följande kopplingar mellan användning av simulator och lärarens samt elevernas arbete i kursen.

\section{Simulatorers och övningars fidelitet}

Elever har en positiv inställning till övningar i simulator inför "verklig körning av maskinen" i termer att "det är bra att lära sig grunderna”. Övningarna upplevs som "bra och verklighetstrogna". Som tidigare nämnts är trösksimulatorn märkesspecifik och detta innebär att reglage, instrumentering och display är detsamma som i den autentiska tröskan. Säkerhet lyfts också som en viktig del i lärprocessen, som också innebär att lära sig grundprincipen för vad som sker inne i 
en tröska. Elevernas kunskaper och erfarenheter av körning av autentiska maskiner är varierande, från mycket stor till elever som inte har kört tröska tidigare. Autenticitet i processen skapas gradvis i övningarna (särskilt Övning 1, Tabell 2) där det instruerande momentet inkluderar mycket stöd i form av ord och bild, som sedan ska memoreras för att genomföra momentet assessment där instruktionerna inte längre ingår. Det instruerande, inledande momentet, där instruktioner ges på engelska, innebär ytterligare ett steg för eleverna, särskilt när det gäller fackuttryck. Momentet öppnar för en möjlighet för att arbeta med en integrering med ämnet engelska dels i form av skapande av ordlistor, dels att stötta eleverna i deras lärande av relevant ämnesinnehåll.

\section{Simulator och ämnesintegrering}

Elevernas kunskaper i engelska visar sig ha en viss betydelse för att genomföra samtliga steg i Övning 1 (Tabell 2). Yrkesläraren beskriver hur det är nödvändigt med stöd (jmf. scaffolding) för att hjälpa eleverna att komma vidare i övningen genom att översätta till svenska. Å andra sidan anger yrkesläraren i sina anteckningar att instruktioner i övningarna även innehåller pilar och bilder som gör att med viss memorering kan elever lösa kommande övningar i både Practice och Assessment. En konsekvens av yrkeslärarens val av simulatorstödd undervisning blir således att scaffolding fyller funktionen att både skapa möjligheter till användning av simulatorn utifrån dess inbyggda övningar och moment utan att avbryta "flow" i upplevelsen, men också att reflektera kring övningen som sådan, där lärarens eller en kamrats stöd blir centralt. För elever med goda kunskaper i engelska är det inga större utmaningar att memorera i Practice för att sedan minnas under Assessment. I övrigt förstår dessa elever sammanhanget bättre. Vikten läggs dock mycket på memorering och repetition i samtliga övningar. Under övning 2-4 har kunskaper i engelska, likväl som i att köra tröskan mindre betydelse. Det är således mer repetition och memorering som gör att eleverna lär sig uppstart och körning i dessa moment, då det gäller för eleverna att ha registrerat instruktioner i form av engelska meningar och av bilder under Practice.

Trafikregler i simulator vid körning av basmaskin (Aktionsforskningsprojekt 3)

Detta projekt fokuserar på körning av basmaskin, i detta fall traktor inom ämnet fordonsteknik. Aktionen identifieras utifrån ett behov av att ge eleverna förutsättningar att utveckla sina kunskaper om trafikregler. Eleverna lär sig trafikregler innan de påbörjar körning i trafik. Simulatorn är då ett pedagogiskt verktyg som används för att träna tillämpning av trafikkunskaper och regler (Figur 8). Eleverna kan få individuell handledning samt fler övningstillfällen. Mer specifikt rör sig frågorna som aktionen vill belysa om möjligheter för eleverna att utveckla samma kunskaper vid körning i simulator som vid körning av traktor på väg 
tillsammans med lärare. Ytterligare en fråga handlar om hur resultat vid simulatorkörning kan ses som tillförlitligt för elevernas förmåga att köra traktor i trafik.
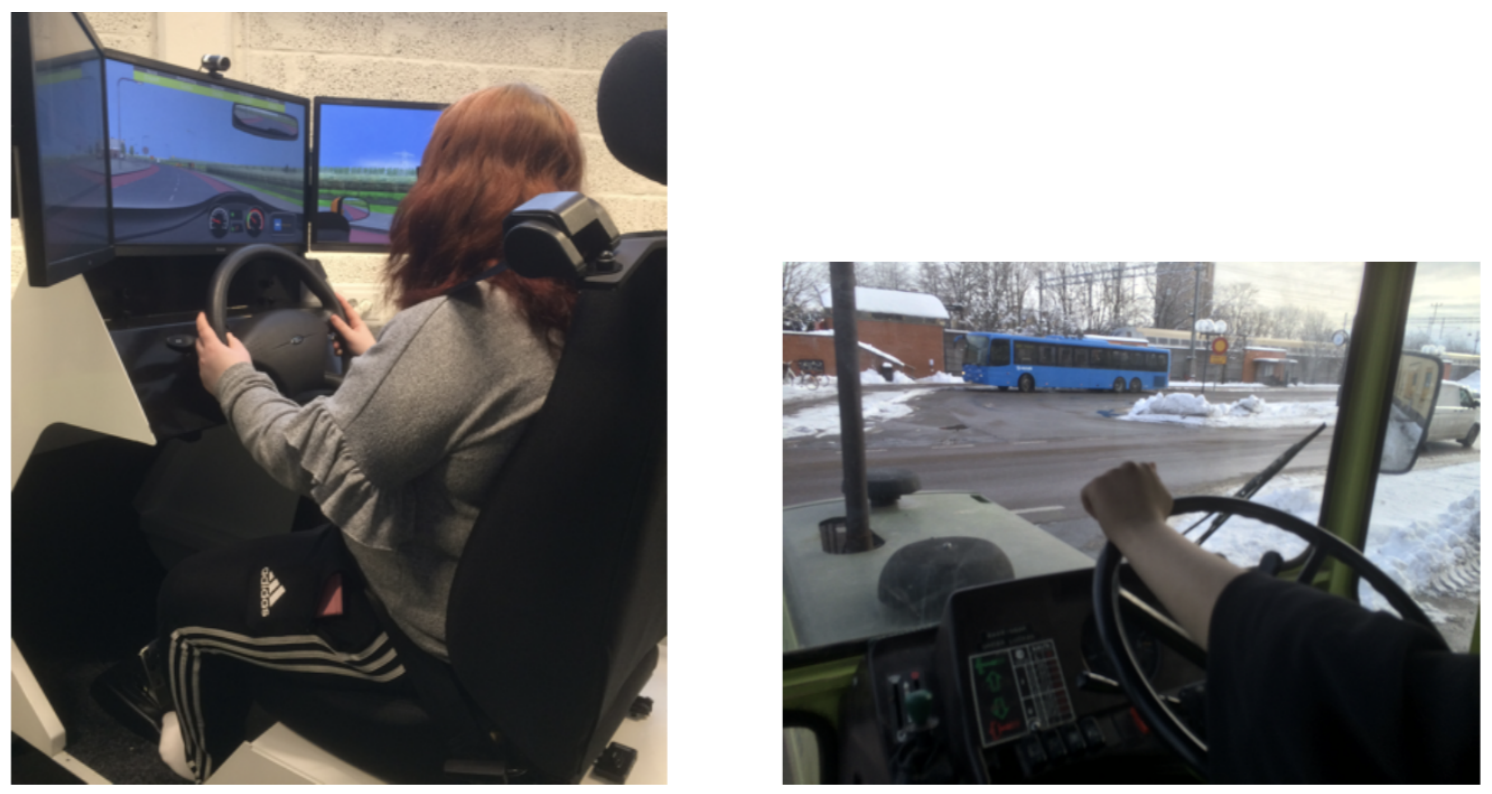

Figur 8. Körning i simulator och med basmaskin i trafik.

Uppföljningen av aktionen består av observationer och detaljerade fältanteckningar av tre elever som går första året på gymnasiesärskolans 4-åriga program med naturbruksinriktning. Aktionen fokuserar på tio tillfällen då eleverna kör en simulator som simulerar körning med bil i trafik, då det i nuläget inte finns någon simulator på marknaden som simulerar körning av basmaskin i tätbebyggt område. Eleverna genomför också en körning i basmaskin. I samband med observationer och under analysen används en matris som stödjer bedömningen av körning i simulator respektive i basmaskin avseende ett antal kriterier, exempelvis regeltillämpning, körning mot mål, vänster- och högersväng. Matrisen är således ett verktyg för läraren för att besvara frågeställningen om huruvida och på vilket sätt träning i simulator kan användas för att ge återkoppling på, samt bedöma specifika delar av körning av basmaskin på ett tillförlitligt sätt. Utöver detta för läraren också anteckningar som inte följer en specifik matris, men som noggrant dokumenterar elevernas beteende vid simulatorövning och vid körning av basmaskin i trafik. Simulatorprogrammet som pågår cirka 40 minuter, avser bilkörning i tätbebyggt område med hastighet $40-50 \mathrm{~km} / \mathrm{h}$. Programmet väljs eftersom det är just dessa omständigheter som liknar körning av basmaskin i trafik, och då särskilt i ett tätbebyggt område. Exemplen nedan, som är utdrag ur lärarens fältanteckningar, illustrerar elevernas agerande under simulatorkörningen och körning i autentisk basmaskin samt delar av lärarens återkoppling. 


\title{
Exempel 1
}

\begin{abstract}
"Känns som riktig trafik"
Melvin startar programmet i simulatorn, det är hans första tillfälle i aktionsforskningen. Han har provat denna simulator en gång tidigare, det var i mitten på höstterminen.

Melvin kommenterar: Känns som riktig trafik.

Melvin har bra koll på koppling, broms och gas, han ligger på rätt varvtal vid växling Simulatorn informerar med text att Melvin "shift too early". Melvin tycker inte själv att han gör något fel. Jag ger information om hur han kan minska hastigheten innan han trampar ner kopplingen vid ett högre varvtal inför en korsning. Vid rödljus sitter Melvin och upprepat gasar lite, släpper och gasar lite mer. Detta registreras inte av simulatorn, åtminstone inte på ett sådant sätt att det ger en omedelbar feedback tillbaka till föraren. Melvin tar till sig instruktioner från simulatorn om au t.ex. titta i backspeglarna.

Melvin ifrågasätter varför simulatorn säger att han inte kan köra i $50 \mathrm{~km} / \mathrm{h}$ genom en korsning som är huvudled där högsta begränsade hastigheten är $50 \mathrm{~km} / \mathrm{h}$. Jag förklarar situationen. Melvin tycker att det fungerar bra med både skriftlig och muntlig information men läser inte all skriftlig information. En del av den är på engelska och han förstår inte alla ord.

Melvin har bra koll på vägmärken och vilka regler som gäller i olika korsningar. Melvin förstod inte att han körde för nära cyklister trots att det stod på skärmen att han körde för nära framförvarande fordon. Han tyckte inte att det fanns några framförvarande fordon då det inte fanns några som kom framifrån. Cyklisterna stod på cykelbanan till höger om bilen och cyklade om bilen och vidare i en vänstersväng framför bilen. Melvin skulle svänga höger med bilen.

Melvin kommenterar när han tycker att simulatorn är för känslig i sin bedömning t.ex. att köra för nära ett annat fordon vid sväng i korsning.
\end{abstract}

Under genomförande av simulatorprogrammet upplevs körningen som mycket verklig av Melvin. Den inbyggda funktionen att ge omedelbar återkoppling när något felaktigt sker ges skriftligt och på engelska, vilket innebär en utmaning för eleven. Yrkesläraren förmedlar simulatorns återkoppling, förklarar och utvecklar den, särskilt när Melvin visar att han inte håller med, eller förstår återkopplingen. Melvin genomför ytterligare en körning i simulator vid ett annat tillfälle och kör mycket bra, enligt lärarens bedömning. Yrkesläraren ställer därför frågan om Melvin vill köra med simulator en gång till eller om han "känner sig mogen att ge sig ut i trafiken och köra MB-track nästa gång. Melvin svarar utan att tveka 
det minsta att han vill köra MB-track nästa gång" (ur fältanteckningar). Yrkeslärarens syfte under denna övning, är att utvärdera och bedöma simulators fidelitet när det gäller elevens kunskap om trafikregler i tätbebyggt område med de maskiner som eleverna ska lära sig att köra under utbildningen. Melvin är vid det här läget redan en relativt erfaren förare som själv kan bedöma simulatorövningens rimlighet och noggrannhet (i termer av fidelitet). Lärarens återkoppling blir, i detta exempel, en slags medling eller förklaring mellan det som eleven bedömer som "rimligt" (eller inte) i den typ av manöver som han ska utföra i simulator och det som ska bedömas, dvs kunskaperna om trafikreglerna, snarare än färdigheten att utföra själva körningen av maskinen. Simulatorn blir således (och är designad som) ett pedagogiskt verktyg med syftet att "scaffold" förarens beteende så att det anpassas till det som är "korrekt" i förhållande till reglerna som ska följas i en "riktig situation" i "riktig trafik". Under de typer av "immersive experiences" som en simulator kan frambringa, blir den riktade återkopplingen (av läraren och/ eller simulator) till föraren en central del av hur erfarenheten kan upplevas som meningsfull i förhållande till elevens tidigare erfarenheter och uppfattningar av sin körning. Återkoppling och det som presenteras i simulatorns olika scenarier kan dock upplevas som en utmaning, ibland av både läraren och eleven under körning i simulator, som vi ser i exemplen nedan.

\section{Exempel 2}

\section{"Det händer inte så snabbt i verkligheten som i simulatorn"}

Jag övningskör med Melvin som vi bestämde vid föregående tillfälle då Melvin körde i simulatorn.

[...]

Melvin, är lugn, koncentrerad och samlad i sin körning. Allt flyter på, bra och han är godkänd på de flesta momenten. Melvin hade vid flera tillfällen bara en hand på ratten och fick påminnas om detta. Han glömde också att blinka vänster vid start från, vägkanten. Vid utfart från, enskild väg med stopplikt till allmän väg genom vänstersväng valde Melvin att placera traktorn på motsatta körfältet, d.v.s., för långt åt vänster. Melvin valde också vid ett par tillfällen lite väl låg växel. Melvin missade vid ett tillfälle ett viktigt vägmärke. Vi diskuterade efter körningen vad Melvin tycker om sin körning, han känner sig nöjd:

M: Tycker att det är lättare att köra traktor i verkligheten än att köra i simulatorn.

L: Vad är det som känns lättare?

M: Det händer inte så snabbt i verkligheten som i simulatorn t.ex. att det kommer cyklister och bilar i olika korsningar. 
Körning i basmaskin i trafik visar sig vara "lättare" för Melvin än körning i simulator. Läraren reflekterar kring detta, och skriver i sina anteckningar att Melvin "uppvisar samma lugn bakom ratten vid körning i trafik som i simulatorn. Han är trygg och säker i sin körning och det är intressant att se att det är likadant vid körning med traktor i trafik som vid körning i simulator". Gränserna med vad som är "riktig" och "autentisk" körning, och dess motsvarighet i körsimulator används i detta exempel som en motsättning där körning i simulator inte upplevs som "på riktigt" på flera olika plan, både när det gäller fidelitet, men också som ett sämre alternativ till körning på vägen eller på körgården med riktiga maskiner.

Utmaningar med att ta emot återkoppling och hantera olika scenarier som uppenbarar sig plötsligt i simulatorn är en utmaning även för Erik och Anna, de två andra eleverna som deltar i aktionen. I Eriks fall, blir simulatorövningar en utmaning för hans tålamod då han hellre vill "vara ute på körgården och köra traktorn" (ur fältanteckningar). Både Erik och Melvin har relativ omfattande körvana. För Anna, å andra sida, som inte har kört i samma omfattning, blir övningar i simulator en viktig del av träningen av just körvana.

\section{Exempel 3}

\section{"Så här bra hade jag inte kunnat köra annars"}

Vi diskuterar efter körningen vad Anna tycker om sin körning, hon känner sig nöjd för att vara första gången som hon kör traktor i trafiken:

A: Tycker att det är lättare att köra traktor i verkligheten än att köra i simulatorn?

L: Vad är det som känns lättare?

A: I verkligheten är det inte cyklister, gående och bilar som "bara ploppar ner", det gör det i simulatorn. Det går så snabbt i simulatorn med sådana och mellan en del korsningar.

1: Har du haft någon nytta av hur du har lärt dig an köra i simulatorn?

A: Ja, det har jag verkligen haft. Så här bra hade jag inte kunnat köra annars. $\mathrm{Nu}$ när jag har lärt mig så här mycket ska mamma och jag gå en handledarkurs och jag ska få börja att övningsköra med bil.

Svårigheten att hantera snabba förändringar vid körning i simulator beskrivs också av Anna i Exempel 3. Anna upplever simulatorn som ett viktigt inslag i sitt lärande för att uppnå större trygghet och körvana. När eleverna hanterar dessa typer av "immersive experiences" under en övning i en körsimulator (Fu-Hsing m.fl., 2013) blir frågan om i vilket pedagogiskt syfte det är önskvärt att hålla isär den "verkliga" från den "autentiska" helt central. Simulatorn utgör, i samtliga 
fall, ett medel för att träna, eller ett alternativ till "riktig körning" som inte är ett mål i sig. Körning i trafik eller på körgården är det som föredras av eleverna vilket innebär att yrkesläraren behöver motivera för att legitimera omfattningen av simulatorövningar.

\section{Simulatorkörning som lärandepraktik i naturbruksutbildning}

De tre aktionsforskningsprojekten har olika frågeställningar, olika ämnesinnehåll och skilda kontexter, men det gemensamma syftet är utgångspunkt för analysen. Analysen visar vilka förutsättningar som kan skapas för undervisningen i körteknik då skolor utrustas med avancerade körsimulatorer för undervisningen. I analysen belyser vi med stöd av TPACK (Herring m.fl., 2008, Mishra \& Koehler, 2006) vad som kännetecknar relationen mellan (ämnes)innehåll (CK), pedagogik (PK) och teknik (TK) (se Figur 1), samt vilken betydelse det får för undervisningen. Vi lyfter också fram vilken roll simulatorer kan spela för att stödja elevens utveckling av yrkeskunnande och övergången till användning av autentiska maskiner.

En central intention med simulatorstödd undervisning är att möjliggöra kopplingar och övergångar mellan övningar i simulator och autentiska arbetsuppgifter - i denna studie gällande körning av skogs- och lantbruksmaskiner. Resultaten av båda aktionerna i Skola B och yrkeslärares reflektioner visar betydande utmaningar när det gäller utveckling av kunskaper i körning av basmaskiner i simulator, mest på grund av att simulatorn inte simulerar körning av basmaskin i trafik. Däremot finns det också möjligheter bestående av ökat antal körtimmar, trygghetsskapande och säkerhet, mindre risk för skador samt för att "tappa ansiktet" framför andra elever. Minskad miljöpåverkan är också en viktig faktor som simulatorstödd undervisning möjliggör.

De nya simulatorernas fidelitet har utvecklats via avancerad grafik, flera skärmar och stolar som rör sig. Det finns även möjlighet till användning av VR-glasögon. Denna avancerade teknik kan i sig skapa bättre förutsättningar för övergångar, så kallad "transfer" och "boundary-crossing" (Aarkrog, 2011; ToumiGröhn \& Engeström, 2003), mellan simulatorövning och autentisk körning. Samtidigt behöver lärarna goda tekniska kunskaper (TK) om vad den avancerade tekniken kan erbjuda för att avgöra hur den kan användas i relation till det ämnesinnehåll (CK) som undervisningen ska riktas mot. Resultatet visar samstämmigt att simulatorövningar skapar nya förutsättningar för undervisningen.

\section{Simulatorkörning och autentisk körning blir komplementära}

Simulatorövningarnas självinstruerande och förutbestämda karaktär skapar möjligheter för elevens självständiga övningar. Yrkesläraren kan välja vilka övningar som elever ska få tillgång till mot bakgrund av sitt pedagogiska kunnande (PK). Simulatorövningar stimulerar samtal om autentisk körning. Yrkesläraren 
bidrar då till en typ av gränsöverskridande, eller "boundary-work" (Berner, 2010) mellan simulatorövning och autentisk situation där yrkesläraren i dialogen med eleven binder samman det simulerade med det autentiska, som i vissa fall enbart yrkesläraren ser eller har kunskap om. Det framgår också att elever som har erfarenhet av autentisk körning kan jämföra den med simulatorkörning och på så sätt tolka simulatorövningarna i förhållande till egen erfarenhet, vilket Korteling med flera (2017) benämner "transfer-of-training". Elever visar i dessa fall förståelse för vilket yrkeskunnande som simulatorkörningen kan bidra med och vad som behöver erfaras i autentisk körning.

Transfer bygger således på idén att det uppstår ett direkt kausalt samband mellan ett kunnande som utvecklas vid simulatorstödd undervisning och yrkeskunnande. Analysen i samtliga aktionsforskningsprojekt visar å andra sidan att det som eleverna gör i en simulatorövning också innefattar ett lärande om hur exempelvis en elev kommer att bli bedömd eller på annat sätt delta i undervisning i en autentisk maskin. Körning på körgården, i skogen, eller i trafiken är exempel på autentiska undervisningssituationer som bygger på lärarens didaktiska kunnande av samtliga dimensioner i TPACK. Det som kännetecknar lärarens arbete med planeringen av simulatorstödd undervisning är att andra och nya möjligheter till reflektion, samarbete, mängdträning skapas, vilket i sin tur bidrar till lärarens reflektion kring hur form, innehåll och artefakter (eller tekniska redskap) hänger samman i en undervisningssituation. TPACK-analysen bidrar till att förstå vilka utmaningar eller begränsningar som simulatorstödd undervisning innebär.

Under YRKSIM-projektet (Figur 2) och dess olika faser är fokus på formen och "de nya simulatorerna" påtagligt. Många av yrkeslärarnas frågor (vilket framkommer i aktionsforskningsprojekt 1) behandlar relationen mellan innehåll (CK) och tekniskt kunnande (TK) om hur simulatorer fungerar och kan användas i undervisningen. Under arbetet med de tre aktionsforskningsprojekten ges yrkeslärarna (och elever i aktionsforskningsprojekt 1) förutsättningar att systematiskt planera, genomföra och granska olika typer av övningar och undervisningsmoment med hjälp av observationsmallar och bedömningsmatriser som synliggör kopplingen till det lärares professionella kunnande, men också kopplingen mellan det kunnande som eleverna utvecklar via simulatorövningar och utveckling av yrkeskunnande i användning av autentiska maskiner.

Lärarnas systematiska arbete under aktionerna och TPACK-analysen synliggör komplexiteten med transfer i yrkesutbildning eftersom det både för eleverna och yrkeslärarna är en utmaning att identifiera vilket yrkeskunnande från simulatorstödd undervisning som sedan används i autentiska situationer, till exempel körning på skolans körgård. Upplevelsen av simulatorövningen som ett spel kan via lärarens gränsöverskridande förhållningssätt riktas mer mot en upplevelse av att genomföra en arbetsuppgift (jfr Fu-Hsing m.fl., 2013). 
Lärarnas interaktion och stöd behövs

I studiens aktioner utgår lärarna från innehållet i aktuella yrkesämnen och vad de uppfattar att simulatorerna skulle kunna bidra med som integrerade i undervisningen. Yrkeslärares professionella val och ställningstagande är beroende av deras kunskap om vilka möjligheter simulatorerna kan erbjuda, men också om vad som inte kan tillgodoses. Simulatorövningen kan betraktas som en resurs som samspelar med andra undervisningsformer, incitament och även ämnesintegrering. I aktionsforskningsprojekt 1 vill lärarna undersöka om simulatorkörning kan bidra till att eleverna utvecklar flyt i kranhantering vid körning av skotare. Det är ett yrkeskunnande som är centralt, och som det tar tid att utveckla genom motorisk träning för automatisering. Lärarnas erfarenhet av tidigare yrkesverksamhet och undervisning bidrar till att de kan urskilja hur simulatorerna kan understödja övergången till körning i autentiska maskiner. Lärarna skapar stödstrukturer som samspelar med simulatorernas övningar som syftar till att synliggöra de aspekter som är centrala för kranhantering och att engagera elever i värderingen av deras kunskapsutveckling.

I planering av simulatorstödd undervisning behövs, förutom innehållskunskap, även kunskap om hur olika undervisningsformer tillsammans kan stödja elevens lärprocess. Simulatorövningar kan betraktas som en resurs som samspelar med andra undervisningsformer och som också främjar ämnesintegrering. Möjligheten till upprepad träning av ett särskilt moment betonas i aktionsforskningsprojekt 3 där lärarens syfte att använda simulatorn som ett verktyg för träning och bedömning, gör att simulatorns fidelitet i förhållande till autentisk körning hamnar i förgrunden. Med andra ord, den färdighet som eleven utvecklar behöver anpassas till övningar i autentisk miljö eller till helt andra typer av uppgifter. Analys av materialet i aktionsforskningsprojekt 2 visar exempelvis hur simulatorn ställer krav på ett annat kunskapsinnehåll än det som aktualiseras i det aktuella yrkesämnet (i det här fallet engelska språket) vilket kan bidra till naturlig och ömsesidig ämnesintegrering.

\section{Simulator som spel skapar datadrivet lärande}

En viktig aspekt av simulatorkörningen är möjligheten att öva riskfritt. Anknytningen till spelidén gör att övningen blir mer realistisk, en händelse där eleven ska klara olika moment. Å andra sidan är övningen i likhet med ett spel orealistisk, genom att eleven kan misslyckas utan större konsekvenser. Den möjligheten innebär att det finns en risk att eleverna inte inser riskbeteenden utan ser simulatorkörningen mer som ett spel. Detta är något som lärarna i aktion 1 betraktar som problematiskt och uttrycker som "negativ inlärning", då risken finns för att det kan påverka körning $\mathrm{i}$ autentiska maskiner negativt. Fu-Hsing med flera (2013) visar också att simulatorernas utformning som spel kan innebära att eleven mer fokuserar mot spelet och inte mot det avsedda ämnesinnehållet. Lärarna 
i aktionsforskningsprojekt 1 menar att de behöver skapa stödstrukturer, exempelvis genom att använda tillbudsrapporter, som ger eleverna möjlighet att reflektera över motsvarande risker i autentisk körning av skogsmaskiner.

Simulatorerna genererar kontinuerligt data som kan bilda underlag för analys, återkoppling och bedömning av varje elevs kunskapsutveckling. I vår studie visar lärarna en avvaktande hållning till användningen av data genererad i simulatorerna, där de vill undersöka mer om hur data kan användas konstruktivt för återkoppling i undervisningen.

Sammanfattningsvis visar analysen att yrkeslärarnas pedagogiska kunnande vid körning med autentiska maskiner inte automatiskt kan föras över till simulatorstödd undervisning (se också Niess, 2011). Yrkeslärare och elever behöver utveckla ett (nytt) kunnande i att förstå, reflektera kring och använda data som genereras i samband med simulatorstödd undervisning. Simulatorn skapar därmed möjligheter, men kräver också välgrundade val och strategier för undervisningen som helhet. Eleven självständiga träning är i likhet med andra uppgifter som kan bearbetas utanför undervisningen i behov av lärarens stöd. En utmaning för yrkesläraren är att "erövra" verktyget så att det tjänar sitt syfte i en didaktisk och pedagogisk planering.

\section{Implikationer för undervisning}

Studiens syfte var att undersöka samt kritiskt granska utmaningar och möjligheter vid simulatorstödd undervisning i gymnasial yrkesutbildning, med fokus på undervisning och på elevers lärprocess. Lärare och forskare har i nära samverkan prövat och studerat ett urval av frågor identifierade av medverkande lärare. Den praktiknära ansatsen ger möjlighet tillsammans med lärare möta och bedriva forskning utifrån yrkespraktikens egna frågor vilket i detta fall ger ett kunskapsbidrag om simulatorstödd undervisning i yrkesutbildning.

Projektens frågeställningar initierades vid ett gemensamt möte (se Figur 1), där aktioner och uppföljningar planerades gemensamt. Yrkeslärare genomförde undervisningsnära aktioner som följdes av forskare som främst gav stöd för det systematiska upplägget av aktionerna. Analys och slutsatser bearbetades i samverkan mellan lärare och forskare. Resultaten spreds i olika sammanhang inklusive genom deltagande på internationella konferenser där både lärare och forskare deltog i. Praktiknära studier kan ses som ett bidrag till utvecklingen av kunskap om undervisning. YRKSIM-projektet blev ett resultat av denna intention, där utgångspunkten var att simulatorer skulle användas i undervisning. Projekten YRKSIM bidrog till att utmaningar och möjligheter vid integrering av teknik i undervisning i termer av att ny didaktisk kunskap kunde synliggöras. Simulatorer utvecklar inte undervisning och verksamheten av sig själva, och utgör inte lösningen. Digitala redskap (i detta fall komplexa redskap som består av 
olika, datadrivna applikationer) behöver integreras som en del i olika undervisningssituationer via ett systematiskt och reflekterande arbete. Studien presenterar exempel på hur detta arbete kan bedrivas. Studien visar dessutom att det finns utvecklingspotential i dessa typer av samarbete då de bidrar till att en skola kan driva sitt utvecklingsarbete (med utgångspunkt i elevers lärande och utveckling). Metoden att använda elevers självskattning har exempelvis inspirerat lärarna att använda den fortsatt i undervisningen. I olika sammanhang betonas lärarens betydelse för en skolas resultat samt att rektorer sällan kan följa det som pågår i undervisningen. Här ser vi hur aktionsforskningsprojekt kan bidra till att lärare involveras direkt i ett systematiskt förbättringsarbete. Studien visar också hur förändringar i den lokala praktiken i form av implementering av ny komplex digital teknik via inköp av mjukvara och hårdvara, inte enbart kan mötas med formell kompetensutveckling utan det behövs också ett systematiskt och praktiknära arbete som lärare utför i sin dagliga undervisning.

\section{Om författarna}

Susanne Gustavsson är universitetslektor i pedagogik vid Institutionen för pedagogik och specialpedagogik vid Göteborgs universitet. Forskningsområde är yrkesutbildningens undervisningspraktik och yrkeslärande i skola och på arbetsplats samt skolutveckling och företrädesvis praktiknära studier och projekt. Hon undervisar i yrkeslärarutbildningen samt har uppdrag i rektorsprogrammet.

Giulia Messina Dahlberg är universitetslektor vid Institutionen för pedagogik och specialpedagogik vid Göteborgs universitet. Giulias forskningsintresse rör kommunikativa praktiker när individer hanterar en rad uppdrag både i och utanför institutionella utbildningssammanhang som ligger över gränserna mellan fysiska och virtuella miljöer. Hon är särskilt intresserad av de sätt på vilka sådana gränser skapas och förhandlas i handling för att ge (eller förhindra) tillgång till lärande och deltagande. I sin forskning och kursutveckling har Messina Dahlberg nyligen arbetat med villkoren för rättvisa och inkludering för studenter med funktionsnedsättningar i högre utbildning. Hon är en aktiv forskare i Vetenskapsrådets projekt PAL, Delaktighet för alla?

Ingrid Berglund är universitetslektor vid Institutionen för pedagogik och specialpedagogik vid Göteborgs universitet. Hennes forskningsintresse finns inom området yrkeskunnande och yrkesdidaktik inom olika yrkesområden i såväl skolförlagt som arbetsplatsförlagt lärande. Användning av digitala redskap i yrkesutbildning är ett av hennes specialintressen, liksom bedömning och betygssättning av yrkeskunnande. Hon är huvudsakligen verksam inom yrkeslärarutbildningen vid Göteborgs universitet. 


\section{Referenser}

Aarkrog, V. (2011). A taxonomy for teaching transfer skills in the Danish VET system. Nordic Journal of Vocational Education and Training, 1(1), 1-13.

Angeli, C. \& Valanides N. (2009). Epistemological and methodological issues for the conceptualization, development, and assessment of ICT-TPCK: Advances in Technological Pedagogical Content Knowledge (TPCK). Computers $\mathcal{E}$ Education, 52, 154-168.

Akkerman, S. \& Bakker, A. (2011). Boundary crossing and boundary objects. Review of Educational Research, 81, 132-169.

Berner, B. (2010). Crossing boundaries and maintaining difference between school and industry: Forms of boundary-work in Swedish vocational education. Journal of Education and Work, 23(1), 27-42.

Cox, S. \& Graham, C.R. (2009). Using an elaborated model of the TPACK framework to analyze and depict teacher knowledge. TechTrends, 53(5), 60-69.

Cox, D.J., Brown, T., Ross, V., Moncrief, M., Schmitt, R., Gaffney, G. \& Reeve, R. (2017). Can youth with autism spectrum disorder use virtual reality driving simulation training to evaluate and improve driving performance? An exploratory study. Journal of Autism and Developmental Disorders, 47(8), 2544-2555.

de Winter, J.C.F., van Leeuwen, P.M. \& Happee, R. (2012). Advantages and disadvantages of driving simulators: A discussion. Proceedings of Measuring Behavior 2012 (Utrecht, the Netherlands, August 28-31, 2012).

Dahlstrom, N., Dekker, S., Van Winsen, R. \& Nyce, J. (2009). Fidelity and validity of simulator training. Theoretical Issues in Ergonomics Science, 10(4), 305-314.

Doering, A., Veletsianos, G., Scharber, C. \& Miller, C. (2009). Using the Technological, Pedagogical, and Content Knowledge framework to design online learning environments and professional development. Journal of Educational Computing Research, 41, 319-346.

Fu-Hsing, T., Charles K., Kuo-Hsun H., Cheng-Ling A. C. \& I-Ying H. (2013). The importance and use of targeted content knowledge with scaffolding aid in educational simulation games. Interactive Learning Environments, 21(2), 116-128.

Gieryn, T. (1983). Boundary-work and the demarcation of science from non-science: Strains and interests in professional ideologies of scientists. American Sociological Review, 48(6), 781-795.

Graham, C.R., Borup, J. \& Smith, N.B. (2012). Using TPACK as a framework to understand teacher candidates' technology integration decisions. Journal of Computer Assisted Learning, 28(6), 530-546.

Hardy, I., Rönnerman, K., Edwards-Groves, C., Fumasoli, T., Stensaker, B. \& Vukasovic, M. (2018). Transforming professional learning: Educational action research in practice. European Educational Research Journal, 17(3), 421-441.

Herring, M.C., Koehler, M.J. \& Mishra, P. (Red.) (2008). Handbook of Technological Pedagogical Content Knowledge (TPCK) for educators. New York: Routledge. 
Hirsch, P., Bellavance, F., Tahari, S. \& Faubert, J. (2015). Towards the validation of a driving simulator-based hazard response test for novice drivers. Proceedings of the Eighth International Driving Symposium on Human Factors in Driver Assessment, Training, and Vehicle design. (Salt Lake City, Utah, USA, June 22-26, 2015).

Llewellyn, S. (1998). Boundary work: Costing and caring in the social services. Accounting, Organizations and Society, 23(1), 23-47.

Korteling, H., Helsdingen, A. \& Sluimer, R. (2017). An empirical evaluation of transfer-of-training of two flight simulation games. Simulation E Gaming, 48(1), 8-35.

Koehler, M.J. \& Mishra, P. (2009). What is technological pedagogical content knowledge? Contemporary Issues in Technology and Teacher Education (CITE), 9(1), 60-70.

Niess, M.L. (2011). Investigating TPACK: Knowledge growth in teaching with technology. Journal of Educational Computing Research, 44(3), 299-317.

Mishra, P. \& Koehler, M.J. (2006). Technological pedagogical content knowledge: A framework for teacher knowledge. Teachers College Record, 108, 1017-1054.

Palak, D. \& Walls, R.T. (2014). Teachers' beliefs and technology practices: A mixed-methods approach. Journal of Research on Technology in Education, 41(4), 417-441.

Petzold, T., Weiss, T., Krems, J.F. \& Bannert, M. (2013). The development of a cognitive skills training to support driver education: Comparing performance of experienced and trained learner drivers. Proceedings of the Seventh International Driving Symposium on Human Factors in Driver Assessment, Training, and Vehicle design. (Bolton Landing, New York, June 16, 2013)

Reimer, B., Fried, R., Mehler, B., Joshi, G., Bolfek, A., Godfrey, K., Zaho, N., Goldin R. \& Biederman, J. (2013). Brief report: Examining driving behavior in young adults with high functioning autism spectrum disorders: A pilot study. Journal of Autism Developmental Disorders, 43, 2211-2217.

Shulman, L.S. (1986). Those who understand: Knowledge growth in teaching. Educational Researcher, 15(2), 4-14.

Shulman, L.S. (1987). Knowledge and teaching: Foundations of the new reform. Harvard Education Review 57,1-21.

Tuomi-Gröhn, T. \& Engeström, Y. (Red.) (2003). Between school and work: New perspectives on transfer and boundary-crossing. Boston: Pergamon.

Voogt, J., Fisser, P., Pareja Roblin, N., Tondeur, J. \& van Braak, J. (2013). Using theoretical perspectives in developing and understanding of TPACK. Journal of Computer Assisted Learning, 29, 109-121. 